\title{
Jurist-Diction
}

Volume 4 No. 5 September 202

\section{Pembuktian Sederhana Pengajuan Permohonan Pailit oleh Pekerja Atas Dasar Upah yang Tidak Dibayar}

\author{
Pramudita
}

\author{
pramudita_purwoko@ymail.com \\ Universitas Airlangga
}

How to cite:

Pramudita, 'Pembuktian

Sederhana Pengajuan

Permohonan Pailit oleh Pekerja

Atas Dasar Upah yang Tidak

Dibayar' (2021) Vol. 4 No. 5

Jurist-Diction.

Histori artikel:

Submit 19 Juli 2021;

Diterima 15 Agustus 2021;

Diterbitkan 1 September 2021.

DOI:

10.20473/jd.v4i5.29826

p-ISSN: 2721-8392

e-ISSN: $2655-8297$

\section{Abstract}

Bankruptcy is a situation where the debtor is unable to perform the obligation to pay debts to his creditors. Which in this modern era is rampant cases of bankruptcy caused by a setback in the financial condition or financial condition of the debtor or company so that they cannot pay debts, one of which is wages as a form of compensation for workers in the company. Workers can submit bankrupt statements to the Commercial Court to their companies to claim their rights, but often the decision is rejected with one of the judges' judgment stating that it cannot be proven simply. Furthermore, when there are parties who are dissatisfied with the decision at the first level, namely the Commercial Court, the party can take further legal remedies namely Cassation to the Supreme Court and Review to the Supreme Court. The purpose of writing this research is to prove that the wages of unpaid workers meet the qualifications of simple proof if the wage shortage has been calculated by labor inspectors as regulated in Article 28 paragraph (1) of the Minister of Manpower Regulation No. 33 of 2016 concerning Labor Inspection Procedures.

Keywords: Bankruptcy; Simple Proof; and Workers.

\section{Abstrak}

Pailit merupakan suatu keadaan dimana debitor tidak mampu untuk melakukan kewajiban membayar utang-utang kepada para kreditornya. Yang mana pada era modern ini sedang marak terjadi kasus pailit yang disebabkan karenaadanyakemunduran dalamkondisifinancialataukondisi keuangan si debitor atau perusahaan sehingga tidak dapat membayar utang yang salah satunya berupa upah sebagai bentuk imbalan untuk pekerja dalam perusahaannya. Pekerja dapat mengajukan permohonan pernyataan pailit ke Pengadilan Niaga terhadap perusahaannya untuk menuntut haknya namun seringkali putusan tersebut ditolak dengan salah satu pertimbangan hakim menyatakan tidak dapat dibuktikan secara sederhana. Selanjutnya ketika ada pihak yang kurang puas dengan putusan pada tingkat pertama yakni Pengadilan Niaga, pihak tersebut dapat melakukan upaya hukum selanjutnya yaitu Kasasi ke Mahkamah Agung dan Peninjauan Kembali ke Mahkamah Agung. Penelitian ini bertujuan untuk membuktikan bahwa upah pekerja yang tidak dibayar memenuhi kualifikasi pembuktian sederhana apabila kekurangan upah tersebut telah dihitung oleh pengawas ketenagakerjaan sebagaimana teratur dalam Pasal 28 ayat (1) Peraturan Menteri Ketenagakerjaan Nomor 33 Tahun 2016 tentang Tata Cara Pengawasan Ketenagakerjaan.

Kata Kunci: Kepailitan; Pembuktian Sederhana; dan Pekerja.

Copyright $(\subset 2021$ Pramudita 


\section{Pendahuluan}

Pailit merupakan suatu keadaan dimana debitor tidak mampu untuk melakukan kewajibannya yaitu membayar utang-utang kepada para kreditornya. Umumnya, para debitor yang tidak mampu membayar utangnya tersebut disebabkan karena adanya kemunduran dalam kondisi financial atau kondisi keuangan si debitor. ${ }^{1}$ Sedangkan kepailitan merupakan putusan pengadilan yang mengakibatkan sita umum atas keseluruhan kekayaan debitor pailit, berupa barang bergerak maupun tidak bergerak, baik yang telah ada maupun yang akan ada di kemudian hari. ${ }^{2}$ Kepailitan merupakan salah satu cara terburuk yang dapat ditempuh oleh kreditor untuk mendapatkan kewajiban pembayaran piutangnya dari debitor miliknya dengan cara dilakukan pengurusan dan pemberesan terhadap harta debitor yang menjadi kewenangan kurator dibawah pengawasan hakim pengawas, dengan tujuan menggunakan hasil penjualan harta kekayaan tersebut untuk membayar seluruh utang debitor pailit secara proposional (protate parte) kepada para kreditor.

Berdasarkan Pasal 2 ayat (1) Undang-Undang Nomor 37 Tahun 2004 tentang Kepailitan dan Penundaan Kewajiban Pembayaran Utang (selanjutnya disebut sebagai UUK-PKPU), debitor dapat diputus pailit ketika mempunyai dua atau lebih kreditor dan tidak membayar lunas sedikitnya satu utang yang telah jatuh waktu dan dapat ditagih. ${ }^{3}$ Siapapun dapat menjadi debitor ketika ia telah terbukti secara sederhana memenuhi fakta-fakta atau syarat-syarat debitor yang disebutkan pada Pasal 2 ayat (1) UUK-PKPU tersebut dan syarat-syarat tersebut dapat dibuktikan secara sederhana sebagaimana teratur di dalam Pasal 8 ayat (4) UUK-PKPU. Permohonan pernyataan pailit dapat dimohonkan sendiri oleh debitor ataupun atas permohonan salah satu atau lebih kreditornya.

Dalam hukum kepailitan sendiri terdapat pengklasifikasian kreditor yang terbagi menjadi 3 (tiga) jenis kreditor guna mengatur urutan prioritas pelunasan utang debitor, yakni kreditor separatis, kreditor preferen, dan kreditor konkuren. Penulisan

\footnotetext{
${ }^{1}$ Hadi Shubhan, Hukum Kepailitan (Kencana 2008).[1].

${ }^{2}$ ibid. [3].

${ }^{3}$ Pasal 2 (1) UU No. 37/2004.
} 
jurnal ini membahas bagaimana jika yang menjadi kreditor adalah seorang pekerja atau buruh yang mengajukan permohonan pernyataan pailit terhadap pengusaha atau pemberi kerjanya sendiri karena belum membayar haknya sebagai pekerja atau buruh berupa upah dalam waktu yang telah disepakati antar pihak. Dilihat dari segi pandang hukum kepailitan, pekerja atau buruh memiliki posisi sebagai kreditor preferen, yakni kreditor yang dapat didahulukan pembayaran utangnya dibandingkan kreditor lainnya karena telah diatur oleh Undang-Undang. Dalam hal ini, aturan tersebut diatur dalam Pasal 95 ayat (4) Undang-Undang Nomor 13 Tahun 2003 tentang Ketenagakerjaan.

Meskipun telah diatur jelas dalam Undang - Undang Ketenagakerjaan bahwa upah pekerja atau buruh merupakan utang yang harus didahulukan pembayarannya daripada utang-utang yang lain, namun dalam praktiknya di dunia persidangan kasus kepailitan, seringkali hakim niaga menolak permohonan pernyataan pailit yang diajukan oleh pekerja atau buruh terhadap perusahaannya dengan salah satu pertimbangan kasus tersebut tidak dapat dibuktikan secara sederhana sesuai tata cara beracara hukum kepailitan sebagaimana diatur dalam Pasal 8 ayat (4) UUKPKPU. Yang mana dalam penjelasannya, yang dimaksud dengan pembuktian sederhana adalah adanya fakta 2 (dua) atau lebih kreditor dan fakta utang yang telah jatuh waktu dan tidak dibayar. Sedangkan perbedaan besarnya jumlah utang yang didalihkan oleh pemohon pailit tidak menghalangi dijatuhkannya putusan pernyataan pailit. ${ }^{4}$ Pekerja atau buruh juga terklasifikasi sebagai kreditor yang mempunyai hak untuk mengajukan permohonan pernyataan pailit sebagai upaya penuntutan hakhaknya, pun Pasal 28D ayat (2) Undang-Undang Dasar Negara Republik Indonesia 1945 juga menyatakan bahwa setiap orang berhak untuk mendapatkan pekerjaan dan mendapat imbalan serta perlakuan yang layak dalam suatu hubungan kerja. ${ }^{5}$ Sehingga kurang adil rasanya jika hakim niaga menolak permohonan pernyataan pailit yang diajukan oleh pekerja atau buruh sebagai kreditor terhadap pengusaha atau pemberi kerjanya dengan dalih tidak dapat dibuktikan secara sederhana. Oleh

\footnotetext{
${ }^{4}$ Penjelasan Pasal 8 (4) UU No. 37/2004.

${ }^{5}$ Pasal 28D (2) UUD 1945.
} 
karenanya dalam penulisan jurnal ini membahas terkait apakah upah pekerja atau buruh memenuhi kualifikasi pembuktian sederhana dan upaya hukum apa saja yang dapat ditempuh oleh para pekerja atau buruh yang upahnya tidak dibayar agar dapat terpenuhi hak-haknya.

\section{Pemenuhan Syarat Pembuktian Sederhana Dalam Pengajuan Kepailitan Oleh Pekerja}

Kepailitan merupakan sita umum terhadap harta kekayaan debitor pailit, yang proses pengurusan dan pemberesan hartanya dilakukan oleh seorang kurator dibawah pengawasan hakim pengawas sebagaimana diatur dalam UUK - PKPU tersebut. Kepailitan juga menjadi salah satu usaha terakhir yang dapat ditempuh dengan penyitaan umum harta debitor ketika debitor berada dalam keadaan insolven atau suatu kondisi dimana debitor memiliki kewajiban yang lebih besar dari nilai seluruh hartanya sehingga membuat debitor tidak sanggup membayar atau insolven. ${ }^{6}$ Sitaan umum tersebut berfungsi untuk para kreditor mendapatkan kewajiban pembayaran atas piutangnya dari debitor pailit, agar para kreditor tidak semakin mengalami kerugian. Sitaan umum yang dimaksud adalah meliputi seluruh harta kekayaan debitor pailit sejak terucapnya putusan pailit terhadap debitor pailit, yang akan digunakan untuk membayar para kreditor menurut besar kecilnya piutang masingmasing kreditor agar tidak berebutan. ${ }^{7}$ Selain keadaan insolven dari debitor seperti yang telah dijelaskan sebelumnya, seseorang atau suatu badan hukum yang hendak mengajukan permohonan kepailitan ke Pengadilan Niaga harus mengetahui betul mengenai syarat-syarat pengajuan permohonan pailit, karena keadaan insolven bukanlah syarat pokok seseorang dapat diajukan permohonan pailit. ${ }^{8}$ Sebagaimana diatur dalam Pasal 2 ayat (1) UUK-PKPU bahwa permohonan pailit dapat diajukan apabila memenuhi syarat-syarat sebagai berikut:

\footnotetext{
${ }^{6}$ Elyta Ras Ginting, Hukum Kepailitan: Teori Kepailitan (Sinar Grafika 2018).[53].

7 Sularto, 'Perlindungan Hukum Kreditur Separatis dalam Kepailitan' (2012) 24 Mimbar Hukum.[247].

${ }^{8}$ Elyta Ras Ginting, Op.Cit.[54].
} 
a. Debitor terhadap yang mengajukan permohonan pailit mempunyai paling sedikit dua kreditor, kreditor yang dimaksud dalam hal ini adalah kreditor baik kreditor separatis, kreditor preferen, maupun kreditor konkuren;

b. Debitor tidak membayar lunas kewajiban atau utangnya terhadap salah satu kreditor atau lebih; dan

c. Utang yang tidak dibayar itu harus telah jatuh waktu dan dapat ditagih (due and payable), ${ }^{9}$ baik karena telah diperjanjikan, karena percepatan waktu penagihan sesuai perjanjian, karena pengenaan sanksi atau denda oleh instansi yang berwenang, ataupun karena putusan pengadilan, arbiter, atau majelis arbitrase. ${ }^{10}$

Perlu dipahami dengan jelas dan rinci mengenai apa yang dimaksud dengan “debitor", "kreditor", dan juga "utang" yang menjadi syarat pokok bagi Pengadilan Niaga dapat mengabulkan permohonan pernyataan pailit dari kreditor terhadap debitor. Pertama debitor sendiri diatur dalam Pasal 1 angka 3 UUK-PKPU, bahwa debitor adalah orang yang mempunyai utang atas perjanjian antar pihak atau Undang-Undang yang pelunasannya dapat ditagih di muka pengadilan karena telah jatuh waktu. Selanjutnya kreditor diatur dalam Pasal 1 angka 2 UUK-PKPU, bahwa kreditor adalah orang yang mempunyai piutang atau meminjami uang kepada orang lain atas perjanjian atau Undang-Undang yang pelunasannya dapat ditagih di muka pengadilan karena telah jatuh waktu. Kreditor disini mencakup seluruh jenis kreditor dalam hukum kepailtian tanpa terkecuali, yakni kreditor separatis, kreditor preferen, dan kreditor konkuren. Undang-Undang tidak membatasi terhadap kreditor jenis apa yang dapat mengajukan permohonan pernyataan pailit terhadap calon debitor pailit, karena semua kreditor mempunyai hak yang sama untuk mendapati pembayaran kewajibannya. ${ }^{11}$ Terakhir terkait penjelasan utang diatur dalam Pasal 1 angka 6 UUK-PKPU, dengan maksud bahwa utang adalah kewajiban yang dapat dinyatakan dalam jumlah uang, baik mata uang Indonesia maupun mata uang asing,

${ }^{9}$ Sutan Remy Sjahdeini, Hukum Kepailitan: Memahami Undang - Undang No. 37 Tahun 2004 tentang Kepailitan (Grafiti 2008).[52].

${ }^{10}$ Sularto, Op.Cit.[248].

${ }^{11}$ Hadi Shubhan, Op.Cit.[75]. 
baik secara langsung maupun yang akan timbul di kemudian hari (kontinjen). Utang dalam ruang lingkup kepailitan, seyogyanya jumlah utang harus telah pasti. Karena jika kewajiban atau utang adalah yang dapat dinyatakan dalam jumlah uang untuk dapat dikategorikan sebagai utang debitor dan dapat didaftarkan ke dalam daftar verifikasi pencocokan utang dan piutang, merujuk pada ke belum pastian "berapa" nilai atau jumlah utangnya, lantas siapa dan bagaimana cara untuk menentukan nilai atau jumlah utang tersebut? Utang yang telah jatuh waktu disini berarti utang yang dapat ditagih, sedangkan perbedaan besarnya jumlah utang yang didalihkan oleh pemohon pailit dan termohon pailit tidak menghalangi dijatuhkannya putusan pernyataan pailit terhadap debitor.

Ketiga syarat debitor tersebut wajib terpenuhi dalam pemeriksaan perkara kepailitan yang dilakukan dengan sistem pembuktian sederhana. Pembuktian sederhana yang diatur dalam Pasal 8 ayat (4) UUK-PKPU, dapat diartikan sebagai permohonan pernyataan pailit harus dikabulkan apabila terdapat keadaan yang terbukti secara sederhana dengan fakta adanya dua atau lebih kreditor serta ada utang yang telah jatuh waktu dan tidak dibayar lunas oleh debitor. Pengertian dari pembuktian sederhana tidak berarti bahwa cara pembuktian sederhana ini dilakukan di luar hukum acara pembuktian yang diatur oleh HIR/Rbg. Karena prinsip-prinsip pembuktian, alat-alat bukti, serta nilai pembuktian masing-masing alat bukti tetap berkaca pada ketentuan umum yang diatur dalam HIR/Rbg. ${ }^{12}$

Utang yang telah jatuh waktu disini berarti utang yang dapat ditagih. Utangyang belum jatuh waktu pun juga dapat ditagih ketika berada di kondisi-kondisi tertentu. Sedangkan perbedaan besarnya jumlah utang yang didalihkan oleh pemohon pailit dan termohon pailit tidak menghalangi dijatuhkannya putusan pernyataan pailit terhadap debitor. Salah satu cara pembuktian keberadaan utang adalah dengan cara kreditor membuktikan telah memberikan teguran kepada debitor untuk membayar utangnya atau membuktikan dengan debitor yang tidak juga membayar utangnya hingga lewat jangka waktu pembayaran kewajiban utang yang telah disepakati

${ }^{12}$ Elyta Ras Ginting, Op.Cit.[322]. 
bersama sebelumnya. Jika pembuktian keberadaan utang tersebut cukup rumit dan sulit untuk dilakukan, bahkan justru menimbulkan sengketa, maka tidak memenuhi syarat pembuktian yang sederhana dalam permohonan pailit. ${ }^{13}$

Dalam praktiknya, penafsiran mengenai pembuktian sederhana kerap ditafsirkan beragam. Beberapa permohonan pernyataan kepailitan, ada permohonan pernyataan kepailitan yang dinilai hakim tidak dapat dibuktikan secara sederhana. Karena Undang - Undang Nomor 37 Tahun 2004 tentang Kepailitan dan Penundaan Kewajiban Pembayaran Utang juga tidak menjelaskan secara rinci dan detail terkait bagaimana pelaksanaan pembuktian sederhana dalam proses pembuktian perkara kepailitan, sehingga penafsiran pada Pasal 8 ayat (4) UUK - PKPU yang mengatur mengenai pembuktian sederhana tersebut ditafsirkan sepenuhnya oleh Majelis Hakim Pengadilan Niaga yang memeriksa dan memutus perkara kepailitan yang bersangkutan. ${ }^{14}$ Salah satu contohnya adalah dalam kasus Perkara Nomor $515 \mathrm{~K} /$ Pdt.Sus/2016, dimana ada utang yang menurut hakim tidak dapat dibuktikan secara sederhana. Pemohon pailit atau dalam kasus tersebut adalah PT. J dan J Garment Indonesia adalah debitor yang mendalihkan bahwa ia mempunyai beberapa kreditor yang salah satunya adalah upah karyawan perusahanya yang belum dibayar sejak bulan Juni 2016 dengan nilai Rp 3 Milyar. Pemohon pailit juga mendalilkan bahwa perseroan memiliki utang terhadap rekanan perusahaan lainnya baik dalam mata uang Rupiah maupun Dollar dengan jumlah mencapai sekitar Rp 3,5 Milyar. Dengan demikian maka eksistensi keberadaan dua kreditor dalam kasus permohonan pailit ini telah terpenuhi dan perusahaan tersebut menjadi debitor dari karyawan yang berposisi menjadi kreditor sehingga dapat melakukan gugatan pailit terhadap perusahaan. Oleh karena itu pertimbangan hakim yang menjadikan perhitungan-perhitungan pembayaran pesangon sebagai alasan permohonan tidak mempunyai landasan hukum yang kuat berdasarkan UU Kepailitan. Pun di dalam

\footnotetext{
${ }^{13}$ Hukum Online, 'Hak Pekerja untuk didahulukan dalam Perkara Kepailitan' (Hukum Online 2017), <https://www.hukumonline.com/berita/baca/hol16924/hak-pekerja-untuk-didahulukandalam-perkara-kepailitan-/>, diakses pada tanggal 1 September 2019.

${ }^{14}$ Nelson Kapoyos, ‘Konsep Pembuktian Sederhana dalam Perkara Kepailitan' (2017) 10 Jurnal Yudisial.[337].
} 
daftar kreditor dari debitor telah tercantum jelas bahwa J Garment Indonesia memiliki 60 (enam puluh) kreditor dan 3 (tiga) diantaranya hadir dalam persidangan serta mengaku mempunyai piutang dari debitor. Dengan demikian seharusnya judex factie mengabulkan permohonan yang diajukan oleh pemohon pailit untuk menyatakan pailit $\mathbf{J}$ Garment Indonesia karena telah terbukti secara sah bahwa J Garment Indonesia sama sekali tidak membayar utang yang telah jatuh waktu dan dapat ditagih kepada para kreditor.

Secara konstitusional, pekerja atau buruh telah mempunyai posisi yang memadahi di dalam Pasal 27 ayat (2) UUD Negara Republik Indonesia 1945, bahwa setiap warga negara Indonesia berhak atas pekerjaan dan penghidupan yang layak bagi kemanusiaan, serta dalam Pasal 28D ayat (2) UUD Negara Republik Indonesia 1945, bahwa setiap orang berhak atas pekerjaan dengan imbalan dan perlakuan yang adil dan layak dalam hubungan kerjanya. Pengupahan pekerja atau buruh juga diatur secara jelas di dalam Undang-Undang Nomor 13 Tahun 2003 tentang Ketenagakerjaan, bahwa setiap pekerja atau buruh berhak memperoleh penghasilan yang memenuhi penghidupan layak bagi kemanusiaan sehingga pemerintah menetapkan kebijakan pengupahan yang melindungi para pekerja atau buruh. ${ }^{15}$ Sehubungan dengan jelas dan rincinya pengaturan terkait pengupahan pekerja atau buruh oleh pemberi kerjanya, kurang adil rasanya ketika permohonan pernyataan pailit yang diajukan oleh pekerja ditolak dengan salah satu pertimbangan hakim bahwa kasus tersebut tidak dapat dibuktikan secara sederhana. Pasal 28 ayat (1) Peraturan Menteri Ketenagakerjaan Republik Indonesia Nomor 33 Tahun 2016 tentang Tata Cara Pengawasan Ketenagakerjaan mengatur bahwa pembuktian upah pekerja yang tidak dibayar oleh perusahaan dapat terkualifikasi pembuktian sederhana apabila kekurangan upah tersebut telah dihitung oleh pengawas ketenagakerjaan.

Dalam segi pandang hukum, pekerja atau buruh mendapati posisi sebagai kreditor preferen yang mana pembayaran utangnya harus didahulukan. Hal

\footnotetext{
${ }^{15}$ Pasal 88 (1) dan (2) UU No. 13/2003.
} 
tersebut dijelaskan dalam Pasal 95 ayat (4) Undang - Undang Nomor 13 Tahun 2003 tentang Ketenagakerjaan dan dipertegas pula oleh Mahkamah Konstitusi melalui Putusan MK Nomor 67/PUU-XI/2013 tanggal 11 September 2014 sebagai pengabulan dari permohonan para pekerja untuk memberi penafiran yang lebih jelas lagi terhadap aturan dalam Pasal 95 ayat (4) Undang - Undang Nomor 13 Tahun 2003 tentang Ketenagakerjaan.

\section{Upaya Hukum Pekerja yang Ditolak Permohonan Kepailitannya Terhadap Perusahaan untuk Menuntut Pemenuhan Upah yang Tidak Dibayar}

Hukum kepailitan digolongkan sebagai hukum publik yang bersifat memaksa. Secara normatif telah disebutkan secara jelas dan tegas pada Pasal 1 angka 7 UUKPKPU bahwa Pengadilan yang dimaksud dalam seluruh isi pasal dalam UUK-KPU ini adalah Pengadilan Niaga dalam lingkungan Peradilan Umum. ${ }^{16}$ Yang mana ketika ada kreditor atau dalam hal ini pekerja atau buruh dapat mengajukan permohonan pernyataan pailit terhadap debitor ke Pengadilan Niaga, karena Pengadilan Niaga lah yang sepenuhnya berwenang menjadi forum resmi untuk menjatuhkan putusan pailit maupun tuntutan hukum.

Hukum kepailitan merupakan salah satu hukum khusus di dalam hukum perdata. Begitu pula dengan Pengadilan Niaga yang merupakan ruang lingkup dari Pengadilan Negeri. Pengadilan Niaga pertama kali didirikan di Pengadilan Negeri Jakarta berdasarkan ketentuan Pasal 281 ayat (1) Peraturan Pemerintah Pengganti Undang-Undang Nomor 1 Tahun 1998 tentang Perubahan Undang- Undang tentang Kepailitan jo. Undang-Undang Nomor 1 Tahun 1998, kemudian dinyatakan tetap berwenang memeriksa dan memutus perkara yang menjadi lingkup Pengadilan Niaga. Dimana Pengadilan Niaga berwenang untuk menerima permohonan Kepailitan dan Penundaan Kewajiban Pembayaran Utang. ${ }^{17}$ Pembentukan Pengadilan Niaga di dalam pembaruan Undang-Undang Kepailitan yakni menjadi UU Nomor 37 Tahun

\footnotetext{
${ }^{16}$ Pasal 1 angka 7 UU No. 37/2004.

${ }^{17}$ Pasal 3 UU No. 37/2004.
} 
2004, merupakan fenomenal diantara berbagai upaya lainnya ${ }^{18}$ dan merupakan terapan dari asas lex specialist derogate legis generali maupun asas integritas yang dianut oleh UUK-PKPU. Pengadilan Niaga mempunyai kekhususan dalam perkara kepailitan yang meliputi:

1) Pengadilan Niaga tidak mengenal banding, sehingga jika ada pihak yang merasa tidak puas dengan putusan di tingkat pertama atau Pengadilan Niaga, pihak tersebut dapat mengajukan upaya hukum langsung ke tingkat Kasasi di Mahkamah Agung;

2) Jangka waktu proses pendaftaran, pemeriksaan, dan penjatuhan putusan pada tingkat Pengadilan Niaga diatur tegas dalam Pasal 8 ayat (5) UUK-PKPU, yaitu paling lambat 60 hari setelah tanggal permohonan pernyataan pailit didaftarkan; dan

3) Jangka waktu pemeriksaan di tingkat kasasi Mahkamah Agung adalah selama 30 hari. $^{19}$

Hukum acara kepailitan berbeda dengan upaya hukum dalam acara perdata biasa lainnya yang mana dalam acara perdata biasa terdapat upaya hukum banding. Hukum acara kepailitan tidak mengenal adanya upaya hukum banding sehingga ketika ada pihak yang tidak puas dengan putusan dalam pengadilan tingkat pertama atau Pengadilan Niaga, ia dapat mengajukan upaya hukum selanjutnya yaitu kasasi ke Mahkamah Agung dan upaya hukum terakhir yaitu Peninjauan Kembali ke Mahakamh Agung. Upaya hukum yang diajukan ke tingkat kasasi Mahkamah Agung tidak hanya mengenai penolakan atau ke tidak puasan para pihak atas putusan yang diucapkan di tingkat pertama. Hal-hal lain yang dapat diajukan upaya hukum kasasi menurut Undang-Undang Nomor 37 Tahun 2004 tentang Kepailitan dan Penundaan Kewajiban Pembayaran Utang, meliputi:

\footnotetext{
${ }^{18}$ Serlika Aprita, Op.Cit.[63].

${ }^{19}$ Hermayulis, Pengadilan Niaga: Eksistensi dan Pernan Pengadilan Niaga sebagai Pengadilan Khusus dalam Penyelesaian Sengketa Niaga, Laporan Akhir Penelitian Bagi Komisi Hukum Nasional Republik Indonesia (2002).[177-178], dikutip dari Serlika Aprita, Op.Cit.[63].
} 
- Pasal 19 ayat (2) UUK-PKPU, kreditor dapat mengajukan kasasi atas putusan pencabutan pernyataan pailit;

- Pasal 160 ayat (1) UUK-PKPU, debitor dan kreditor yang menyetujui perdamaian dapat mengajukan upaya hukum kasasi ke Mahkamah Agung terhadap putusan Pengadilan Niaga yang menolak mengesahkan perdamaian;

- Pasal 160 ayat (2) huruf a UUK-PKPU, kreditor yang tidak menyetujui perdamaian dapat mengajukan permohonan kasasi atas putusan Pengadilan Niaga yang mengesahkan perdamaian;

- Pasal 160 ayat (2) huruf b UUK-PKPU, kreditor yang menyetujui perdamaian dapat mengajukan upaya hukum kasasi ke Mahkamah Agung untuk membatalkan putusan pengesahan perdamaian, manakala diketahui bahwa perdamaian tersebut seharusnya ditolak untuk disahkan karena hal-hal sebagai berikut:

a. Harta debitor termasuk benda yang hak untuk menahan suatu benda ternyata jauh lebih besar daripada jumlah yang disetujui dalam perdamaian;

b. Pelaksanaan perdamaian tidak cukup terjamin bahwa perdamaian akan tercapai, karena penipuan atau persekongkolan dengan satu atau lebih kreditor; atau

c. Karena pemakaian upaya lain yang tidak jujur dan tanpa menghiraukan apakah debitor atau pihak lain bekerjasama untuk mencapai hal tersebut. ${ }^{20}$

- Pasal 196 ayat (1) juncto Pasal 194 ayat (6) UUK-PKPU, kurator atau setiap kreditor dapat mengajukan upaya kasasi ke Mahkamah Agung atas putusan majelis di hakim prosedur renvoi mengenai perlawanan atas daftar pembagian yang diajukan oleh kreditor yang keberatan atas isi daftar pembagian tersebut. ${ }^{21}$

Penghapusan upaya hukum banding dalam hukum kepailitan ini dikonstruksikan untuk memangkas jalur kepailitan agar jalur acara perkara kepailitan lebih cepat dibandingkan dengan acara perdata biasa lainnya. Hal ini selaras dengan sistem pembuktian sederhana yang diterapkan dalam hukum acara kepailitan. Karena sebenarnya, hakikat pengadilan tingkat banding adalah sama dengan pengadilan tingkat pertama, yaitu sama-sama sebagai pengadilan judex factie atau memeriksa bukti-bukti dan menentukan fakta-fakta dari perkara tersebut. Sehingga adanya upaya banding tidak memberikan nilai tambah bagi para pencari keadilan (justiabelen). Oleh karenanya tidak ada masalah dengan tidak adanya upaya hukum banding dalam hukum kepailitan melainkan langsung upaya hukum kasasi ke Mahkamah Agung. ${ }^{22}$

${ }^{20}$ Pasal 159 ayat (2) Undang-Undang Nomor 37 Tahun 2004 tentang Kepailitan dan Penundaan Kewajiban Pembayaran Utang.

${ }^{21}$ Elyta Ras Ginting, Op.Cit.[343].

${ }^{22}$ Hadi Shubhan, Op.Cit.[127]. 
Selain dapat mengajukan permohonan pernyataan pailit melalui lembaga pengadilan hukum kepailitan secara umum, pekerja dapat melakukan upaya untuk menuntut pemenuhan haknya sebagai pekerja melalui jalur non pengadilan, ketika terdapat perselisihan hak atau perselisihan kepentingan. Yakni melaporkannya kepada Panitia Penyelesaian Perburuhan. Perselisihan hak adalah perselisihan yang timbul karena salah satu pihak pada perjanjian kerja tersebut tidak memenuhi isi perjanjian atau menyalahi ketentuan hukum dalam perjanjian tersebut. Yang berwenang menyelesaikan perselisihan hak tersebut adalah Panitia Penyelesaian Perburuhan dan juga Pengadilan Negeri. Namun terdapat 2 (dua) perbedaan pokok yaitu: ${ }^{23}$

a. Yang dapat menuntut di muka Panitia Penyelesaian Perselisihan Perburuhan hanyalah majikan dan organisasi pekerja tidak perseorangan, sedangkan yang dapat menuntut di muka Pengadilan Negeri adalah pekerja; dan

b. Sanksi putusan Panitia Penyelesaian Perselisihan Perburuhan dapat dikenakan sanksi pidana kurungan selama-lamanya 3 (tiga) bulan atau denda setinggitingginya Rp10.000,- (sepuluh ribu rupiah), sedangkan sanksi putusan Pengadilan Negeri adalah semata-mata sanksi perdata.

Di samping adanya perselisihan hak, ada pula perselisihan kepentingan yang merupakan pertentangan terkait dengan tidak adanya persesuaian paham mengenai syarat-syarat kerja dan/atau keadaan perburuhan. ${ }^{24}$ Terkait adanya perselisihan kepentingan tersebut, pekerja atau buruh maupun pengusaha atau pemberi kerja hanya dapat mengajukan penyelesaian perselisihan kepentingan ke Panitia Penyelesaian Perselisihan Perburuhan, tidak dapat diajukan ke Pengadilan Negeri.Lembaga Penyelesaian Perselisihan Hubungan Industrial diatur dalam Undang-Undang Nomor 2 Tahun 2004 tentang Penyelesaian Perselisihan Hubungan Industrial yang menjadi lembaga untuk menangani pertentangan antara pengusaha atau gabungan pengusaha dengan pekerja atau buruh atau serikat buruh karena adanya perselisihan

${ }^{23}$ Iman Soepomo, Pengantar Hukum Perburuhan, (Djambatan 1990). [44], dikutip dari Lanny Ramli, Hukum Ketenagakerjaan (Airlangga University Press 2008).[47].

${ }^{24}$ Lanny Ramli, Hukum Ketenagakerjaan (Airlangga University Press 2008).[47]. 
hak, kepentingan, pemutusan kerja, dan perselisihan antar serikat pekerja atau buruh dalam suatu perusahaan. ${ }^{25}$ Apabila pemberi kerja tidak memberikan upah tepat pada waktu yang telah ditentukan selama 3 (tiga) bulan berturut-turut atau lebih, pekerja atau buruh dapat mengajukan permohonan pemutusan hubungan kerja kepada lembaga penyelesaian perselisihan hubungan industrial. ${ }^{26}$ Dalam ketentuan Undang-Undang Nomor 2 Tahun 2004 tentang Penyelesaian Perselisihan Hubungan Industrial, prosedur penyelesaian perselisihan hubungan industrial dapat ditempuh melalui 2 (dua) upaya hukum, yaitu melalui jalur Pengadilan maupun di luar Pengadilan.

Untuk penyelesaian perselisihan di luar Pengadilan, dapat ditempuh melalui 4 (empat) tahap, yaitu:

a. Bipartite, yaitu mekanisme proses perundingan yang dilakukan antara dua pihak (pengusaha atau pemberi kerja dan pekerja atau buruh). Atau dengan kata lain, tahap bipartite dapat disebut sebagai penyelesaian secara negosiasi. Yaitu upaya dengan tanpa melibatkan pihak lain untuk mencapai kesepakatan bersama atas dasar kerjasama yang harmonis. ${ }^{27}$

b. Mediasi, yaitu cara mencapai kesepakatan atas perselisihan antar pihak dengan bantuan seorang mediator atau orang ketiga yang netral (tidak berpihak kepada salah satu pihak). Mediator merupakan sala satu pegawai instansi yang bertanggungjawab di bidang ketenagakerjaan. ${ }^{28}$

c. Konsiliasi, yaitu upaya alternative. Artinya upaya ini bersifat pilihan sukarela (voluntary), bukan bersifat wajib (mandatory) sebagaimana upaya mediasi sebelumnya. ${ }^{29}$ Upaya konsiliasi ini dilakukan oleh seseorang atau beberapa orang, atau badan sebagai penengah yang disebut sebagai konsiliator dengan mempertemukan atau memberi fasilitas kepada para pihak yang berselisih untuk menyelesaikan perselisihannya secara damai. Upaya ini terbilang hampir sama dengan upaya mediasi, namun yang membedakan adalah konsiliator atau orang ketiga dalam upaya konsiliasi ini bukan merupakan pegawai dari instansi yang bertanggungjawab di bidang ketenagakerjaan.

d. Arbitrase, sama halnya seperti upaya konsiliasi. Upaya arbitrase merupakan upaya alternative yang dapat dipilih atau bersifat sukarela (voluntary). ${ }^{30}$

\footnotetext{
${ }^{25}$ Maryana, Op.Cit. [84].

${ }^{26}$ Pasal 169 UU 13/2003.

${ }^{27}$ Lalu Husni, Pengantar Hukum Ketenagakerjaan Indonesia (Rajarafindo Persada 2001). [53], dikutip dari Maryana, Op.Cit.[88].

${ }^{28}$ ibid. [92].

${ }^{29}$ Abdul Khakim, Op.Cit.[278-288], dikutip dari Maryana, Op.Cit.[91].

${ }^{30}$ Pasal 29 dan Pasal 54 UU 2/2004.
} 
Ke-empat tahap diatas dapat ditempuh oleh pekerja atau buruh untuk menuntut hak-haknya sebelum mengajukan upaya hukum langsung ke Pengadilan. Karena upaya-upaya di luar Pengadilan tidak banyak membutuhkan waktu, tenaga, serta biaya yang lebih dibandingkan jika langsung mengajukan ke Pengadilan Niaga sebagai upaya hukum yang dapat ditempuh pada tingkat pertama.

\section{Kesimpulan}

Pengajuan permohonan pernyataan pailit oleh pekerja dengan dasar upah yang tidak dibayar memenuhi kualifikasi pembuktian sederhana apabila kekurangan upah tersebut telah dihitung oleh pengawas ketenagakerjaan sebagaimana teratur dalam Pasal 28 ayat (1) Peraturan Menteri Ketenagakerjaan Republik Indonesia Nomor 33 Tahun 2016 tentang Tata Cara Pengawasan Ketenagakerjaan. Hasil perhitungan upah pekerja tersebut dapat diajukan dalam pemeriksaan kasus kepailitan di tingkat pertama atau yang secara normatif dalam Pasal 1 angka 7 UUK - PKPU dijelaskan bahwa Pengadilan yang dimaksud dalam seluruh isi pasal tersebut adalah Pengadilan Niaga. Hukum kepailitan tidak mengenal upaya hukum banding seperti lazimnya hukum acara perdata biasa lainnya sehingga upaya hukum yang dapat ditempuh setelah tingkat pertama adalah upaya hukum kasasi ke Mahkamah Agung dan upaya hukum terakhir adalah peninjauan kembali ke Mahkamah Agung. Sebelum langsung mengajukan upaya hukum ke tingkat pertama, pekerja dapat melakukan upaya hukum di luar pengadilan terlebih dahulu seperti Bipartite, Mediasi, Konsiliasi, atau Arbitrase.

\section{Daftar Bacaan}

\section{Buku}

Elyta Ras Ginting, Hukum Kepailitan: Teori Kepailitan (Sinar Grafika 2018).

Hadi Shubhan, Hukum Kepailitan Prinsip; Norma dan Praktik di Pengadilan (Kencana 2015).

Lanny Ramli, Hukum Ketenagakerjaan (Airlangga University Press 2010). 
Sutan Remy Sjahdeini, Hukum Kepailitan: Memahami Undang-Undang No. 37 Tahun 2004 tentang Kepailitan (Grafiti 2008).

\section{Jurnal}

Nelson Kapoyos, 'Konsep Pembuktian Sederhana dalam Perkara Kepailitan’ (2017) 10 Jurnal Yudisial.

Sularto, 'Perlindungan Hukum Kreditur Separatis dalam Kepailitan' (2012) 24 Mimbar Hukum.

\section{Laman}

Hukum Online, Hak Pekerja untuk didahulukan dalam Perkara Kepailitan (Hukum Online 2017) < https://www.hukumonline.com/berita/baca/holl6924/hakpekerja-untuk-didahulukan-dalam-perkara-kepailitan-/>, dikunjungi pada tanggal 1 September 2019.

\section{Tesis}

Maryana, Perlindungan Hukum Terhadap Hak-Hak Pekerja dalam Hukum Kepailitan (2010) Tesis Program Pascasarjana Fakultas Hukum Universitas Islam Indonesia. 
1936 Pramudita: Pembuktian Sederhana Pengajuan...

--halaman ini sengaja dibiarkan kosong-- 